\title{
COMBINED EFFECTS OF CADMIUM AND DECABROMINATED DIPHENYL ETHER ON THYROID HORMONES IN RATS
}

\author{
Marijana ĆURČIĆ ${ }^{1}$, Saša JANKOVIĆ ${ }^{2}$, Vesna JAĆEVIĆ ${ }^{3}$, Sanja STANKOVIĆ ${ }^{4}$, Slavica \\ VUČINIĆ $^{3}$, Ksenija DURGO ${ }^{5}$, Zorica BULAT ${ }^{1}$, and Biljana ANTONIJEVIĆ ${ }^{1}$ \\ Department of Toxicology “Akademik Danilo Soldatović, Faculty of Pharmacy, University of Belgrade ${ }^{1}$, Institute of \\ Meat Hygiene and Technology', Poison Control Center, Military Medical Academy ${ }^{3}$, Department of Biochemistry, \\ Faculty of Pharmacy, University of Belgrade 4 , Belgrade, Serbia, Department for Biochemical Engineering, Faculty of \\ Food Technology and Biotechnology, University of Zagreb ${ }^{5}$, Zagreb, Croatia
}

Received in December 2011

CrossChecked in August 2012

Accepted in August 2012

\begin{abstract}
The aim of this study was to see how a mixture of cadmium $(\mathrm{Cd})$ and decabrominated diphenyl ether (BDE209) affect thyroid function, namely thyroid-stimulating hormone (TSH), thyroxin (T4), free thyroxin (FT4), triiodothyronin (T3), and free triiodothyronin (FT3) in Wistar rats (eight per group) receiving either a single substance or their combination by gavage for 28 days. Three groups were receiving $\mathrm{Cd}$ alone in the doses of $2.5 \mathrm{mg} \mathrm{kg}^{-1}, 7.5 \mathrm{mg} \mathrm{kg}^{-1}$, or $15 \mathrm{mg} \mathrm{kg}^{-1} \mathrm{~b}$. w. a day, three groups were receiving BDE209 in the doses of $1000 \mathrm{mg} \mathrm{kg}^{-1}, 2000 \mathrm{mg} \mathrm{kg}^{-1}$, or $4000 \mathrm{mg} \mathrm{kg}^{-1} \mathrm{~b}$. w. a day, while nine groups were receiving different mixtures of $\mathrm{Cd}$ and BDE209 in these doses ( $3 \times 3$ design). The results have indicated that the Cd+BDE209 mixtures more potently disrupt thyroid hormone homeostasis than would be expected from these chemicals alone.
\end{abstract}

KEY TERMS: $B D E 209, C d$, thyroid-stimulating hormone, thyroxin, triiodothyronin

Chemical risk assessment procedures commonly rely on determining the effects of a single substance. Over the last decade, however, a number of welldesigned studies have investigated the effects of multi-component mixtures (1-4). High-level exposure to cadmium $(\mathrm{Cd})$ is usually a result of environmental contamination due to various anthropogenic activities $(5,6)$. Acute or chronic exposure to $\mathrm{Cd}$ can affect the liver, kidney, bone, and testes in humans and experimental animals (7-13). In addition, there is evidence that $\mathrm{Cd}$ can alter thyroid function $(6,14-$ 17).

Flame retardants have also become very important environmental and occupational pollutants. Through history, BDE209 was thought to be released minimally into the environment during all phases of its use and not available biologically due to its large molecular size and low aqueous solubility. However, today it is a widespread environmental contaminant with evidence demonstrating its bioaccumulation and toxic potential (18-23). Recent studies with polybrominated diphenyl ethers (PBDEs) have shown that they disturb liver enzyme activity and thyroid hormone function (24-29), reduce epididymal sperm function (30), and may affect the nervous system and newborns (31, 32).

Cadmium and BDE209 are jointly present in the environmental media, food, biota, and human tissues 
through several pathways as a result of emission from various sources. Combined exposure to $\mathrm{Cd}$ and organic pollutants may result in complex toxicity. In view of the importance of in vivo behaviour of contaminants concomitantly present in an organism, this study was aimed at determining the effects of mixtures of $\mathrm{Cd}$ and BDE209 on thyroid-stimulating hormone (TSH), thyroxin (T4), free thyroxin (FT4), triiodothyronin (T3), and free triiodothyronin (FT3) in rats.

\section{MATERIALS AND METHODS}

\section{Experimental animals}

Male albino Wistar rats weighing $200 \mathrm{~g}$ to $240 \mathrm{~g}$ were obtained from a disease-free stock bred at the Military Medical Academy in Belgrade, Serbia. The animals were housed in plastic cages with a plastic bottom and wire mesh top, in a climate-controlled facility with a constant 12-hour day and night cycle at $20{ }^{\circ} \mathrm{C}$ to $24{ }^{\circ} \mathrm{C}$ and relative humidity between $40 \%$ and $60 \%$. The animals had free access to food and tap water throughout the study and were treated according to the guidelines for animal studies (no. 9667-1/2011) issued by the Academy's ethics committee.

After a quarantine period of 14 days, groups of eight animals each were receiving either a single substance or their combinations by gavage in a volume of $0.5 \mathrm{~mL} \mathrm{~kg}^{-1}$ b.w. per day for 28 days. Three groups were receiving $\mathrm{Cd}$ alone in the form of $\mathrm{CdCl}_{2} \mathrm{x} \mathrm{H}_{2} \mathrm{O}$ (Merck, Darmastadt, Germany) in the doses of $2.5 \mathrm{mg} \mathrm{kg}^{-1}, 7.5 \mathrm{mg} \mathrm{kg}^{-1}$, or $15 \mathrm{mg} \mathrm{kg}^{-1}$ b. w. per day $\left(\mathrm{Cd}_{25}, \mathrm{Cd}_{75}\right.$, and $\mathrm{Cd}_{15}$, respectively) and three groups BDE 209 alone as a suspension in dimethyl sulphoxide (DMSO, Sigma-Aldrich, St. Louis, MO, USA) in the doses of $1000 \mathrm{mg} \mathrm{kg}^{-1}, 2000 \mathrm{mg} \mathrm{kg}^{-1}$, or $4000 \mathrm{mg} \mathrm{kg}^{-1}$ b. w. perday (BDE209 ${ }_{1000}, \mathrm{BDE} 209_{2000}$, and BDE209 ${ }_{4000}$, respectively). Cadmium doses were selected to reflect environmental to occupational exposure $(7,9,16)$. The choice of BDE209 doses was based on literature data on its very low absorption rate of $0.3 \%$ to $2 \%$ $(18,19)$. The remaining nine groups were receiving combinations of $\mathrm{Cd}$ and BDE209 doses according to the $3 \times 3$ design.

Before gavage $\mathrm{Cd}$ salt and BDE209 were dissolved in DMSO.

Rats in the vehicle control group were receiving DMSO alone (DMSO group), while control animals were receiving saline (control group).
We did our best to minimise the suffering and the number of animals used. Throughout the study, the rats were continuously monitored for body weight, clinical signs such as changes in the skin, fur, eyes, mucous membranes, secretions and excretions, autonomic activity (lacrimation, piloerection, pupil size, unusual respiratory patterns), behaviour, and food and water intake. Signs of toxicity were monitored on a daily basis, while water and food intake were recorded weekly. After decapitation, blood was collected from the carotid arteries in glass tubes and then centrifuged at $3000 \times g$ for $30 \mathrm{~min}$. The supernatant (serum) was transferred to polypropylene test tubes and stored at $-70{ }^{\circ} \mathrm{C}$ until thyroid hormone analysis.

\section{Hormone analysis}

Serum samples were analysed for thyroidstimulating hormone, thyroxin, triiodothyronin, and free triiodothyronin with commercial tests using a Roche Elecsys 2010 analyser (Roche Diagnostics, Mannheim, Germany). Values for T3 and T4 are expressed as nmol L-1, for FT3 and FT4 as pmol L-1 while for TSH as $\mathrm{mU} \mathrm{L}^{-1}$. The analytical ranges were $0.005 \mathrm{mU} \mathrm{L}^{-1}$ to $100 \mathrm{mU} \mathrm{L}^{-1}$ for TSH, $0.30 \mathrm{nmol} \mathrm{L}^{-1}$ to $10 \mathrm{nmol} \mathrm{L}^{-1}$ for T3, $5.40 \mathrm{nmol} \mathrm{L}^{-1}$ to $320 \mathrm{nmol} \mathrm{L}^{-1}$ for T4, $0.40 \mathrm{pmol} \mathrm{L}^{-1}$ to $50 \mathrm{pmol} \mathrm{L}^{-1}$ for FT3, and $0.30 \mathrm{pmol} \mathrm{L}^{-1}$ to $100 \mathrm{pmol} \mathrm{L}^{-1}$ for FT4. Total precisions over these ranges (expressed as coefficients of variance) were $5.4 \%$ for TSH, $4.8 \%$ for T3, $3.3 \%$ for T4, $2.2 \%$ for FT3, and $2.7 \%$ for FT4.

\section{Statistical analysis}

To establish significance of differences between the groups, we used one-way analysis of variance (ANOVA) and subsequently Tukey's paired comparisons or Fisher's least significant difference (LSD) as post hoc tests. The level of statistical significance for all tests was set at $p<0.05$. All data were analysed using the statistical package Statistica 7.0.

\section{RESULTS}

Slower body weight gain was the most common in groups treated with the combination of compounds (in eight out of nine groups), while Cd or BDE209 alone did not cause significant changes compared to controls (Table 1). However, water and food consumption did not differ significantly between animals receiving single compounds (Cd or BDE209) and animals receiving their combinations. 
Table 1 Body weight and food and water intake in Wistar rats orally exposed to BDE209, Cd, or their combinations for 28 days.

\begin{tabular}{|c|c|c|c|c|}
\hline \multirow[b]{2}{*}{ Group } & \multicolumn{2}{|c|}{ Body weight / g } & \multicolumn{2}{|c|}{ Daily consumption } \\
\hline & Final & Gain & Food / g & Water / mL \\
\hline Control & $312.50 \pm 5.01$ & $115.7 \pm 9.04$ & $40.75 \pm 1.50$ & $73.25 \pm 5.32$ \\
\hline DMSO & $300.04 \pm 14.14$ & $85.00 \pm 19.15$ & $30.00 \pm 8.89$ & $53.00 \pm 14.61$ \\
\hline $\mathrm{Cd}_{2.5}$ & $331.25 \pm 24.16$ & $107.50 \pm 26.05$ & $24.51 \pm 2.33 \mathrm{a}$ & $45.66 \pm 2.37 \mathrm{a}$ \\
\hline $\mathrm{Cd}_{7.5}$ & $290.00 \pm 52.15$ & $80.00 \pm 31.62$ & $20.03 \pm 3.15 \mathrm{a}$ & $36.35 \pm 3.08 \mathrm{a}, \mathrm{b}$ \\
\hline $\mathrm{Cd}_{15}$ & $304.29 \pm 20.70$ & $82.86 \pm 24.98 \mathrm{a}$ & $17.51 \pm 3.38 \mathrm{a}, \mathrm{b}$ & $37.53 \pm 5.66 \mathrm{a}$ \\
\hline BDE209 ${ }_{1000}$ & $317.50 \pm 19.08$ & $113.80 \pm 16.85 b$ & $22.92 \pm 4.02 \mathrm{a}$ & $44.58 \pm 12.58 \mathrm{a}$ \\
\hline BDE209 ${ }_{2000}$ & $305.00 \pm 18.71$ & $88.00 \pm 10.95 \mathrm{a}$ & $25.00 \pm 5.47 \mathrm{a}$ & $41.68 \pm 16.01 \mathrm{a}$ \\
\hline BDE209 ${ }_{4000}$ & $291.67 \pm 48.75$ & $84.00 \pm 25.10 \mathrm{a}$ & $27.08 \pm 1.58 \mathrm{a}$ & $43.77 \pm 4.15 \mathrm{a}, \mathrm{b}$ \\
\hline $\mathrm{Cd}_{2.5}+\mathrm{BDE} 209_{1000}$ & $286.25 \pm 27.74$ & $81.30 \pm 26.96 \mathrm{a}, \mathrm{c}, \mathrm{d}$ & $21.56 \pm 4.72 \mathrm{a}$ & $34.37 \pm 11.38 \mathrm{a}$ \\
\hline $\mathrm{Cd}_{7.5}+\mathrm{BDE} 209_{1000}$ & $258.33 \pm 41.19$ & $20.00 \pm 1.41 \mathrm{a}, \mathrm{b}, \mathrm{c}, \mathrm{d}$ & $18.30 \pm 11.03 \mathrm{a}$ & $30.45 \pm 15.28 \mathrm{a}, \mathrm{b}$ \\
\hline $\mathrm{Cd} \mathrm{d}_{15}+\mathrm{BDE} 209_{1000}$ & $261.43 \pm 48.11$ & $66.67 \pm 30.77 \mathrm{a}, \mathrm{d}$ & $23.84 \pm 5.55 \mathrm{a}$ & $32.41 \pm 10.53 \mathrm{a}, \mathrm{b}$ \\
\hline $\mathrm{Cd}_{2.5}+\mathrm{BDE} 209_{2000}$ & $243.33 \pm 30.11$ & $26.00 \pm 8.94 \mathrm{a}, \mathrm{b}, \mathrm{c}, \mathrm{d}$ & $18.75 \pm 12.58 \mathrm{a}$ & $26.25 \pm 18.33 \mathrm{a}$ \\
\hline $\mathrm{Cd}_{7.5}+\mathrm{BDE} 209_{2000}$ & $270.00 \pm 24.49$ & $71.67 \pm 20.41 \mathrm{a}$ & $22.08 \pm 5.49 \mathrm{a}$ & $50.42 \pm 22.14$ \\
\hline $\mathrm{Cd}_{15}+\mathrm{BDE} 209_{2000}$ & $215.00 \pm 8.37$ & $20.00 \pm 7.07 \mathrm{a}, \mathrm{b}, \mathrm{c}, \mathrm{d}$ & $16.48 \pm 7.69 \mathrm{a}$ & $29.15 \pm 4.79 a, b, d$ \\
\hline $\mathrm{Cd}_{2.5}+\mathrm{BDE} 209_{4000}$ & $250.01 \pm 38.47$ & $22.50 \pm 8.25 \mathrm{a}, \mathrm{b}, \mathrm{c}, \mathrm{d}$ & $20.82 \pm 5.19 \mathrm{a}$ & $45.85 \pm 4.79 \mathrm{a}$ \\
\hline $\mathrm{Cd}_{7.5}+\mathrm{BDE} 209_{4000}$ & $228.00 \pm 10.95$ & $30.00 \pm 10.95 \mathrm{a}, \mathrm{b}, \mathrm{c}, \mathrm{d}$ & $19.57 \pm 4.17 \mathrm{a}$ & $41.28 \pm 0.85 \mathrm{a}, \mathrm{b}$ \\
\hline $\mathrm{Cd}_{15}+\mathrm{BDE} 209_{4000}$ & $232.00 \pm 21.68$ & $57.50 \pm 23.63 a, d$ & $20.82 \pm 3.21 \mathrm{a}$ & $33.75 \pm 11.15 \mathrm{a}$ \\
\hline
\end{tabular}

$C d_{25}, C d_{75}$, and $C d_{15}$ receiving $C d$ alone in a daily dose of $2.5 \mathrm{mg} \mathrm{kg}^{-1}, 7.5 \mathrm{mg} \mathrm{kg}^{-1} \mathrm{or}_{15} \mathrm{mg} \mathrm{kg}^{-1} \mathrm{~b}$. w., respectively

$B D E 209_{1000^{\circ}} B D E 209_{2000^{\circ}}$ and BDE209 ${ }_{4000}$ - receiving BDE209 alone in a daily dose of $1000 \mathrm{mg} \mathrm{kg}^{-1}, 2000 \mathrm{mg} \mathrm{kg}^{-1}$, or $4000 \mathrm{mg} \mathrm{kg}^{-1}$ b. w., respectively

a - significantly different from control; $b$ - significantly different from the DMSO group; $c$ - significantly different from the same $C d$ dose; $d$ - significantly different from the same BDE209 dose (one way ANOVA and post-hoc Fisher's Least Significant Difference (LSD) test, $p<0.05$ )

Food consumption was lower in all groups compared to control, and the $\mathrm{Cd}_{15}$ group also showed a significant decrease compared to the DMSO group (Table 1). Groups treated with combinations did not differ in food consumption from groups treated with Cd or BDE209 alone. Water consumption decreased in all groups compared to control, with the exception of the $\mathrm{Cd}_{7.5}+\mathrm{BDE} 209_{2000}$ group. Compared to the DMSO group, only the $\mathrm{Cd}_{7.5}$ and the BDE209 ${ }_{4000}$ groups showed lower water consumption, and the same effect was observed in the following four combination groups: $\mathrm{Cd}_{7.5}$ or $\mathrm{Cd}_{15}+\mathrm{BDE} 209_{1000}$, $\mathrm{Cd}_{15}+\mathrm{BDE} 209_{2000}$ and $\mathrm{Cd}_{7.5}+\mathrm{BDE} 209_{4000}$. The only statistically significant difference between the combination groups and corresponding singlecompound groups was noticed for the $\mathrm{Cd}_{15}+\mathrm{BDE} 209_{2000}$ $v s$. BDE209 ${ }_{2000}$ group; the first drank about $30 \%$ less water than the BDE209 ${ }_{2000}$ group. Decreases in food and water intake of almost $50 \%$ in some groups are in accordance with lower body weight gain. Except for food and water intake and body weight gain, there were no other clinical signs of poisoning.

All three $\mathrm{Cd}$ doses induced a significant decrease in T4 and FT4 levels $v s$. control, whereas $2.5 \mathrm{mg} \mathrm{kg}^{-1}$ $\mathrm{Cd}$ led to a decrease in FT3 and $15 \mathrm{mg} \mathrm{kg}^{-1} \mathrm{Cd}$ to decrease in T3 and FT3 levels (Table 2). Significant differences from the DMSO group were seen in the $\mathrm{Cd}_{2.5}$ (FT4), $\mathrm{Cd}_{7.5}$ (FT3, T4), and $\mathrm{Cd}_{15}$ (FT3) groups. Similar to Cd alone, all three doses of BDE209 induced a significant decrease in T4 and FT4 levels vs. control. Compared to the DMSO group, a significant decrease in hormone levels, given in brackets, was observed in the BDE209 ${ }_{1000}(\mathrm{FT} 3, \mathrm{~T} 4)$, BDE209 ${ }_{2000}$ (FT3, T4, FT4), and BDE209 ${ }_{4000}$ (T3) groups. 
Combinations added to these effects, particularly in the groups receiving BDE209 (1000 mg kg-1 or $2000 \mathrm{mg} \mathrm{kg}^{-1}$ ) plus Cd (all three doses). Cd+BDE209 $\left(1000 \mathrm{mg} \mathrm{kg}^{-1}\right)$ significantly decreased T4 and FT4 levels compared to the groups given the corresponding doses of either Cd or BDE209. BDE209 (2000 mg $\mathrm{kg}^{-1}$ ) plus Cd also significantly decreased T4 and FT4, and additionally $\mathrm{T} 3$ levels. We measured TSH levels as well, but they were all below the limit of detection $\left(0.005 \mathrm{mU} \mathrm{L}^{-1}\right)$.

Statistical analysis of the ratio between $\mathrm{T} 3$ and $\mathrm{T} 4$ pointed out that it was significantly higher in almost all groups compared to control. In the $\mathrm{Cd}_{75}$ group and in the groups receiving combinations $\mathrm{Cd}_{2.5}+\mathrm{BDE} 209_{1000}$ and $\mathrm{Cd}_{2.5}+\mathrm{BDE} 209_{2000}$ this ratio was also significantly higher than in the DMSO group. All Cd combinations with the highest dose of BDE209 also showed a significant increase in respect to treatment with corresponding dose of BDE209 alone. Expressed in percentages, the ratio between $\mathrm{T} 3$ and $\mathrm{T} 4$ varied from $5 \%$ to $27 \%$, while in groups $\mathrm{Cd}+\mathrm{BDE} 209_{4000}$ it varied from $10 \%$ to $18 \%$, compared to the DMSO group.

\section{DISCUSSION}

Both pollutants, alone or in combination lowered thyroid hormone levels compared to control, but the combined effect was more pronounced. The combined effect on the levels of T3, FT3, T4, and FT4 may be viewed as additive. A number of studies have already shown that $\mathrm{Cd}$ alters thyroid function in experimental

Table 2 Serum thyroid hormone levels in Wistar rats orally exposed to Cd, BDE209, or their combinations for 28 days

\begin{tabular}{|c|c|c|c|c|c|}
\hline & \multicolumn{4}{|c|}{ Thyroid hormone levels } & Ratio \\
\hline Group & T3 / nmol L ${ }^{-1}$ & FT3 / pmol L ${ }^{-1}$ & T4 / nmol L-1 & FT4 / pmol L ${ }^{-1}$ & T3/T4 \\
\hline Control & $1.52 \pm 0.06$ & $4.57 \pm 0.19$ & $82.66 \pm 3.36$ & $42.51 \pm 2.22$ & 0.0183 \\
\hline DMSO & $1.46 \pm 0.05$ & $4.37 \pm 0.33$ & $62.93 \pm 4.45 \mathrm{a}$ & $32.85 \pm 4.18 \mathrm{a}$ & 0.0232 \\
\hline $\mathrm{Cd}_{2.5}$ & $1.40 \pm 0.13$ & $3.29 \pm 0.24 \mathrm{a}$ & $54.66 \pm 4.11 \mathrm{a}$ & $27.88 \pm 3.15 a, b$ & $0.0256 \mathrm{a}$ \\
\hline $\mathrm{Cd}_{7.5}$ & $1.40 \pm 0.15$ & $3.69 \pm 0.45 b$ & $47.43 \pm 9.04 \mathrm{a}, \mathrm{b}$ & $23.84 \pm 3.60 \mathrm{a}$ & $0.0295 a, b$ \\
\hline $\mathrm{Cd}_{15}$ & $1.34 \pm 0.10 \mathrm{a}$ & $3.56 \pm 0.25 \mathrm{a}, \mathrm{b}$ & $54.90 \pm 4.40 \mathrm{a}$ & $29.44 \pm 2.65 \mathrm{a}$ & $0.0244 \mathrm{a}$ \\
\hline BDE209 ${ }_{1000}$ & $1.39 \pm 0.06 \mathrm{a}$ & $2.98 \pm 0.87 \mathrm{a}, \mathrm{b}$ & $53.84 \pm 5.51 \mathrm{a}, \mathrm{b}$ & $31.02 \pm 2.88 \mathrm{a}$ & $0.0258 \mathrm{a}$ \\
\hline BDE209 ${ }_{2000}$ & $1.44 \pm 0.09$ & $4.72 \pm 0.73 b$ & $49.61 \pm 6.77 \mathrm{a}, \mathrm{b}$ & $25.31 \pm 3.31 \mathrm{a}, \mathrm{b}$ & $0.0290 \mathrm{a}$ \\
\hline BDE209 ${ }_{4000}$ & $1.30 \pm 0.12 \mathrm{a}, \mathrm{b}$ & $4.38 \pm 0.79$ & $61.85 \pm 8.02 \mathrm{a}$ & $29.82 \pm 3.82 \mathrm{a}$ & 0.0210 \\
\hline $\mathrm{Cd}_{2.5}+\mathrm{BDE} 209_{1000}$ & $1.34 \pm 0.05 \mathrm{a}$ & $3.33 \pm 0.17 \mathrm{a}$ & $47.48 \pm 4.04 \mathrm{a}, \mathrm{b}, \mathrm{c}$ & $24.15 \pm 3.00 \mathrm{a}, \mathrm{b}, \mathrm{c}, \mathrm{d}$ & $0.0282 \mathrm{a}, \mathrm{b}$ \\
\hline $\mathrm{Cd}_{7.5}+\mathrm{BDE} 209_{1000}$ & $1.38 \pm 0.06 \mathrm{a}$ & $4.01 \pm 0.20$ & $64.48 \pm 4.12 \mathrm{a}, \mathrm{c}, \mathrm{d}$ & $31.00 \pm 3.36 \mathrm{a}, \mathrm{b}, \mathrm{c}$ & 0.0214 \\
\hline $\mathrm{Cd}_{15}+\mathrm{BDE} 209_{1000}$ & $1.30 \pm 0.05 \mathrm{a}, \mathrm{b}$ & $3.22 \pm 0.31 \mathrm{a}, \mathrm{b}$ & $47.78 \pm 7.74 a, b, c$ & $24.32 \pm 2.28 \mathrm{a}, \mathrm{b}, \mathrm{c}, \mathrm{d}$ & $0.0272 \mathrm{a}$ \\
\hline $\mathrm{Cd}_{2.5}+\mathrm{BDE} 209_{2000}$ & $1.28 \pm 0.14 \mathrm{a}, \mathrm{b}, \mathrm{c}, \mathrm{d}$ & $4.09 \pm 0.50 \mathrm{c}$ & $43.46 \pm 5.42 \mathrm{a}, \mathrm{b}, \mathrm{c}$ & $22.31 \pm 2.49 \mathrm{a}, \mathrm{b}, \mathrm{c}$ & $0.0295 \mathrm{a}, \mathrm{b}$ \\
\hline $\mathrm{Cd}_{7.5}+\mathrm{BDE} 209_{2000}$ & $1.27 \pm 0.12 \mathrm{a}, \mathrm{b}, \mathrm{c}, \mathrm{d}$ & $3.81 \pm 0.53 \mathrm{~d}$ & $47.43 \pm 7.58 \mathrm{a}, \mathrm{c}, \mathrm{d}$ & $25.32 \pm 3.62 \mathrm{a}, \mathrm{b}$ & $0.0268 \mathrm{a}$ \\
\hline $\mathrm{Cd}_{15}+\mathrm{BDE} 209_{2000}$ & $1.22 \pm 0.17 \mathrm{a}, \mathrm{b}, \mathrm{c}, \mathrm{d}$ & $3.83 \pm 0.33 \mathrm{~d}$ & $47.13 \pm 8.58 \mathrm{a}, \mathrm{b}, \mathrm{c}$ & $24.29 \pm 3.27 \mathrm{a}, \mathrm{b}, \mathrm{c}$ & $0.0259 \mathrm{a}$ \\
\hline $\mathrm{Cd}_{2.5}+\mathrm{BDE} 209_{4000}$ & $1.31 \pm 0.15 \mathrm{a}, \mathrm{b}$ & $3.94 \pm 0.49 \mathrm{c}$ & $51.41 \pm 14.21 \mathrm{a}, \mathrm{b}, \mathrm{d}$ & $28.11 \pm 5.22 \mathrm{a}, \mathrm{b}$ & $0.0255 \mathrm{a}, \mathrm{d}$ \\
\hline $\mathrm{Cd}_{7.5}+\mathrm{BDE} 209_{4000}$ & $1.32 \pm 0.14 \mathrm{a}, \mathrm{b}$ & $4.09 \pm 0.26$ & $48.11 \pm 4.60 \mathrm{a}, \mathrm{b}$ & $23.90 \pm 2.22 \mathrm{a}, \mathrm{d}$ & $0.0274 \mathrm{a}, \mathrm{d}$ \\
\hline $\mathrm{Cd}_{15}+\mathrm{BDE} 209_{4000}$ & $1.43 \pm 0.10$ & $4.52 \pm 0.53 \mathrm{c}$ & $54.15 \pm 7.65 a, b$ & $29.03 \pm 4.15 \mathrm{a}$ & $0.0264 \mathrm{a}, \mathrm{d}$ \\
\hline
\end{tabular}

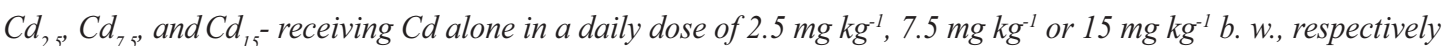

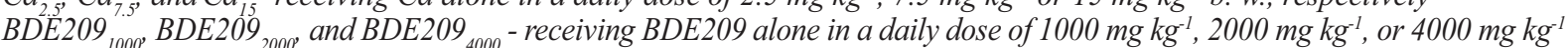
b. w., respectively

a - significantly different from control; $b$ - significantly different from the DMSO group; $c$ - significantly different from the same $C d$ dose; $d$-significantly different from the same BDE209 dose (one way ANOVA and post-hoc Fisher's Least Significant Difference (LSD) test, $p<0.05$ ). 
animals $(6,7,9,14,15-17,33)$ and humans (34). Yoshizuka et al. (17) suggested that $\mathrm{Cd}$ accumulated in the mitochondria of thyroid follicular epithelial cells might disturb the oxidative phosphorylation of this organelle, lower energy supply, and therefore inhibit the synthesis and release of thyroid hormones. Similarly, Pilat-Marcinkiewicz et al. (16) observed a dose-dependent effect on the structure and function of thyroid follicular cells in rats. Apart from the studies suggesting that $\mathrm{Cd}$ interferes with the thyroid function at the glandular level, there are findings supporting the effects at the peripheral level by inhibiting the conversion of T4 to T3 $(14,35-38)$. Thyroid hormones are metabolised in peripheral tissue by deiodination, conjugation, deamination, and decarboxylation enzyme reactions, and any change in these metabolic pathways may significantly affect thyroid function at the cellular level (35-37). As deiodination of T4 to T3, which occurs mainly in the liver, depends on 5'monodeiodinase activity $(35,37)$, hepatic dysfunction is likely to affect thyroid hormone levels (36), T3 in particular. However, thyroid hormone levels are mainly regulated by the hypothalamic-pituitarythyroid axis and if this axis is affected by $\mathrm{Cd}$, so will hormone release $(39,40)$.

Several reports have shown that a broad range of chemicals to which humans are routinely and inadvertently exposed can bind to thyroid receptors (TRs) and may produce complex effects on thyroid hormone signalling (41-43). Polybrominated diphenylethers, structurally related to BDE209, have been also recognised to bind to TRs and perhaps mimic thyroid hormones $(42,43)$. We may therefore assume that BDE209 binds to thyroid receptors rather than acts through the hypothalamic-pituitary axis. However, Zhou et al. (28) found that decaBDE caused no changes in any of the thyroid hormone levels (28). In contrast, Kim et al. (44) found significant increases in thyroid weight of pregnant rats exposed to high doses of BDE209 and significantly lower concentrations of T4 in F1 female offspring exposed to BDE209 on postnatal day 42. In a recent study, Lee et al. (22), found significantly lower total serum $\mathrm{T} 3$ concentrations, degenerated follicular epithelium, and hepatocyte hypertrophy and vacuolisation in newborn rats exposed to BDE209. These findings confirm that BDE209 might affect thyroid hormone synthesis and metabolism.

The combination of $\mathrm{Cd}$ and BDE209 toxicity has even more pronounced effects on T3 and T4, which can be explained by different mechanisms of their action. Although, we assumed additive response, future studies should look into the type of interactions between $\mathrm{Cd}$ and BDE209 at dose levels relevant for human exposure.

\section{Acknowledgement}

This work was partly supported by the Ministry of Education, Science and Technological Development of Serbia (Project III 46009).

\section{REFERENCES}

1. European Commission (EC). State of the Art Report on Mixture Toxicity. Final Report. 2009 [displayed 16 July 2012]. Available at http://ec.europa.eu/environment/ chemicals/pdf/report_Mixture\%20toxicity.pdf

2. Litens S, Esteban J, Schrenk D, Germer S, Van der Ven L, Håkansson H. Morphological and biochemical changes in the livers of Wistar rats following subacute exposure to three technical brominated flame retardant mixtures. Toxicol Lett 2008;180(Supplement):S52.

3. Pelletier G, Masson S, Wade MJ, Nakai J, Alwis R, Mohottalage S, Kumarathasan P, Black P, Bowers WJ, Chu I, Vincent R. Contribution of methylmercury, polychlorinated biphenyls and organochlorine pesticides to the toxicity of a contaminant mixture based on Canadian Arctic population blood profiles. Toxicol Lett 2009;184:17685.

4. Gregoraszczuk EL, Milczarek K, Wójtowicz AK, Berg V, Skaare JU, Ropstad E. Steroid secretion following exposure of ovarian follicular cells to three different natural mixtures of persistent organic pollutants (POPs). Reprod Toxicol 2008;25:58-66

5. Nordberg GF. Cadmium metabolism and toxicity. Environ Physiol Biochem 1972;2:7-36.

6. Hammouda F, Messaoudi I, El Hani J, Baati T, Saïd K, Kerken, A. Reversal of cadmium-induced thyroid dysfunction by selenium, zinc, or their combination in rat. Biol Trace Elem Res 2008;126:194-203.

7. U.S. Department of Health and Human Services, Public Health Service, Agency for Toxic Substances and Disease Registry. Draft Toxicological Profile for Cadmium 2008 [displayed 16 July 2012]. Availble at http://www.atsdr.cdc. gov/toxprofiles/tp5.pdf

8. Saïd L, Banni M, Kerkeni A, Saïd K, Messaoudi I. Influence of combined treatment with zinc and selenium on cadmium induced testicular pathophysiology in rat. Food Chem Toxicol 2010;48:2759-65.

9. International Program on Chemical Safety (IPSC). Cadmium. Environmental Health Criteria 134. Geneva; WHO; 1992.

10. Lazarus M. Međudjelovanje kadmija i selenija u sisavaca [Cadmium and selenium interaction in mammals, in Croatian]. Arh Hig Rada Toksikol 2010;61:357-68.

11. Cvjetko P, Tolić S, Šikić S, Balen B, Tkalec M, VidakovićCifrek Ž. Effect of copper on the toxicity and genotoxicity of cadmium in duckweed (Lemna minor L.). Arh Hig Rada Toksikol 2010;61:287-96. 
12. Matović V, Buha A, Bulat Z, Đukić-Ćosić D. Cadmium toxicity revisited: focus on oxidative stress induction and interactions with zinc and magnesium. Arh Hig Rada Toksikol 2011;62:65-75.

13. Knežević Z, Serdar M. Procjena rizika od izloženosti ljudi pesticidima unesenim hranom [Risk Assessment of human exposure to pesticide in food, in Croatian]. Arh Hig Rada Toksikol 2011;62:269-77.

14. Gupta P, Kar A. Cadmium induced thyroid dysfunction in chicken: hepatic type I iodothyronine 5 '-monodeiodinase activity and role of lipid peroxidation. Comp Biochem Physiol C Pharmacol Toxicol Endocrinol 1999;123:39-44.

15. Piłat-Marcinkiewicz B, Sawicki B, Brzóska MM, MoniuszkoJakoniuk J. Effect of chronic administration of cadmium on the rat thyroid: radioimmunological and immunohistochemical studies. Folia Histochem Cytobiol 2002;40:189-90.

16. Piłat-Marcinkiewicz B, Malgorzata M, Brzóska MM, Sawicki B, Jakoniuk JM. Structure and function of thyroid follicular cells in female rats chronically exposed to cadmium. Bull Vet Inst PuLawy 2003;47:157-63.

17. Yoshizuka M, Mori N, Hamasaki K, Tanaka I, Yokoyama M, Hara K, Doi YX, Umezu Y, Araki H, Sakamoto Y, Miyazaki M, Fujimoto S. Cadmium toxicity in the thyroid gland of pregnant rats. Exp Mol Pathol 1991;55:97-104.

18. Darnerud PO, Eriksen GS, Jóhannesson T, Larsen PB, Viluksela M. Polybrominated diphenyl ethers: occurrence, dietary exposure, and toxicology. Environ Health Perspect 2001;109(Suppl 1):49-68.

19. Darnerud PO, Atuma S, Aune M, Bjerselius R, Glynn A, Grawé KP, Becker W. Dietary intake estimations of organohalogen contaminants (dioxins, PCB, PBDE and chlorinated pesticides, e.g. DDT) based on Swedish market basket data. Food Chem Toxicol 2006;44:1597-606.

20. Daubié S, Bisson J-F, Lalonde R, Schroeder H, Rychen G. Neurobehavioral and physiological effects of low doses of polybrominated diphenyl ether (PBDE)-99 in male adult rats. Toxicol Lett 2011;204:57-63.

21. Frederiksen M, Vorkamp K, Thomsen M, Knudsen EL. Human internal and external exposure to PBDEs-A review of level and sources. Int J Hyg Environ Health 2009;212:10934.

22. Lee E, Kim TH, Choi JS, Nabanata P, Kim NY, Ahn MY, Jung KK, Kang IIH, Kim TS, Kwack SJ, Park KL, Kim SH, Kang TS, Lee J, Lee BM, Kim HS. Evaluation of liver and thyroid toxicity in Sprague-Dawley rats after exposure to polybrominated diphenyl ether BDE-209. J Toxicol Sci 2010;35:535-45.

23. Wang F, Wang J, Dai J, Hu G, Wang J, Luo X, Mai B. Comparative tissue distribution, biotransformation and associated biological effects by decabromodiphenyl ethane and decabrominated diphenyl ether in male rats after a 90-day oral exposure study. Environ Sci Technol 2010;44:565560.

24. Fowles JR, Fairbrother A, Baecher-Steppan L, Kerkvliet NI. Immunologic and endocrine effects of the flame-retardant pentabromodiphenyl ether (DE-71) in C57BL/6J mice. Toxicology 1994;86:49-61.

25. Hallgren S, Sinjari T, Håkansson H, Darnerud P. Effects of polybrominated diphenyl ethers (PBDEs) and polychlorinated biphenyls (PCBs) on thyroid hormone and vitamin a levels in rats and mice. Arch Toxicol 2001;75:200-8.
26. Hallgren S, Darnerud PO. Polybrominated diphenyl ethers (PBDEs), polychlorinated biphenyls (PCBs) and chlorinated paraffins $(\mathrm{CPs})$ in rats - testing interactions and mechanisms for thyroid hormone effects. Toxicology 2002;177:227-43.

27. Skarman E, Darnerud PO, Öhrvik H, Oskarsson A. Reduced thyroxine levels in mice perinatally exposed to polybrominated diphenyl ethers. Environ Toxicol Pharmacol 2005;19:27381.

28. Zhou T, Ros DG, De Vito MJ, Crofton KM. Effects of shortterm in vivo exposure to polybrominated diphenyl ethers on thyroid hormones and hepatic enzyme activities in weanling rats. Toxicol Sci 2001;61:76-82.

29. Zhou T, Taylor MM, De Vito MJ, Crofton KM. Developmental exposure to brominated diphenyl ethers results in thyroid hormone disruption. Toxicol Sci 2002;66:105-16.

30. Tseng LH, Lee CW, Pan MH, Tsai SS, Li MH, Chen JR, Lay JJ, Hsu PC. Postnatal exposure of the male mouse to $2,2^{\prime}, 3,3^{\prime}, 4,4^{\prime}, 5,5^{\prime}, 6,6^{\prime}$-decabrominated diphenyl ether: Decreased epididymal sperm functions without alterations in DNA content and histology in testis. Toxicology 2006;224:33-43

31. Chen J, Liufu C, Sun W, Sun X, Chen D. Assessment of the neurotoxic mechanisms of decabrominated diphenyl ether (PBDE-209) in primary cultured neonatal rat hippocampal neurons includes alterations in second messenger signalling and oxidative stress. Toxicol Lett 2010;192:4319.

32. Goodman JE. Neurodevelopmental effects of decabromodiphenyl ether (BDE-209) and implications for the reference dose. Regul Toxicol Pharm 2009;54:91-104.

33. Lafuente A, Cano P, Esquifino AI. Are cadmium effects on plasma gonadotropins, prolactin, ACTH, GH and TSH levels, dose-dependent? Biometals 2003;16:243-50.

34. Iijima K, Otake T, Yoshinaga J, Ikegami M, Suzuki E, Naruse H, Yamanaka T, Shibuya N, Yasumizu T, Kato N. Cadmium, lead, and selenium in cord blood and thyroid hormone status of newborns. Biol Trace Elem Res 2007;119:10-8.

35. Chaurasia SS, Gupta P, Kar A, Maiti PK. Free radical mediated membrane perturbation and inhibition of TYPE-I iodothyronine 5 '-monodeiodinase activity by lead and cadmium in rat liver homogenate. Biochem Mol Biol Int 1996;39:765-70.

36. Kelly GS. Peripheral metabolism of thyroid hormones: a review. Altern Med Rev 2000;5:306-33.

37. Paier B, Hagmuller K, Noli MI, Gonzalez Pondal M, Stiegler $\mathrm{C}$, Zaninovich AA. Changes induced by cadmium administration on thyroxine deiodination and sulfhydryl groups in rat liver. J Endocrinol 1993;138:219-24.

38. Gupta P, Chaurasia SS, Maiti PK, Kar A. Cadmium induced alterations in extrathyroidal conversion of thyroxine to triiodothyronine by type-I iodothyronine 5'-monodeiodinase in male mouse. Horm Metab Res 1997;29:151-2.

39. Chiamolera MI, Wondisford FE. Minireview: Thyrotropinreleasing hormone and the thyroid hormone feedback mechanism. Endocrinology 2009;150:1091-6.

40. Pavia Jr MA, Paier B, Noli MI, Hagmüller K, Zaninovich AA. Evidence suggesting that cadmium induces a nonthyroidal illness syndrome in the rat. J Endocrinol 1997;154:113-7.

41. Chana A, Concejero MA, de Frutos M, González MJ, Herradón B. Computational studies on biphenyl derivatives. Analysis of the conformational mobility, molecular 
electrostatic potential, and dipole moment of chlorinated biphenyl: searching for the rationalization of the selective toxicity of polychlorinated biphenyls (PCBs). Chem Res Toxicol 2002;15:1514-26.

42. Zoeller RT. Environmental chemicals as thyroid hormone analogues: new studies indicate that thyroid hormone receptors are targets of industrial chemicals? Mol Cell Endocrinol 2005;242:10-5.
43. Zoeller RT. Environmental chemicals impacting the thyroid: targets and consequences. Thyroid 2007;17:811-7.

44. Kim TH, Lee YJ, Lee E, Kim MS, Kwack SJ, Kim KB, Chung KK, Kang TS, Han SY, Lee J, Lee BM, KIM HS. Effects of gestational exposure to decabromodiphenyl ether on reproductive parameters, thyroid hormone levels, and neuronal development in Sprague-Dawley rats offspring. J Toxicol Environ Health A 2009;72:1296-303. 


\section{Sažetak}

\section{KOMBINIRANO DJELOVANJE KADMIJAI DEKABROMIRANOG DIFENIL ETERA NA HORMONE ŠTITNJAČE U ŠTAKORA}

Cilj ovoga istraživanja bio je utvrditi na koji način smjesa kadmija $(\mathrm{Cd})$ i dekabromiranog difenil etera (BDE209) djeluje na aktivnost štitnjače. Određivane su aktivnosti stimulirajućega hormona štitnjače (TSH), tiroksina (T4), slobodnog tiroksina (FT4), trijodtironina (T3) te slobodnog trijodtironina (FT3) kao parametara koji upućuju na funkcionalnost štitnjače. Kao eksperimentalni testni sustav korišteni su Wistar štakori ( $\mathrm{n}=8$ po grupi), kojima je tijekom 28 dana dozirana pojedinačna tvar ili smjesa kadmija i dekabromiranog difeniletera. Životinje su bile podijeljene u tri grupe koje su primale tri različite doze kadmija: $2,5 \mathrm{mg} \mathrm{kg}^{-1}, 7,5 \mathrm{mg} \mathrm{kg}^{-1}$ i $15 \mathrm{mg} \mathrm{kg}^{-1}$ tjelesne težine po danu. Tri grupe životinja primale su tri različite doze BDE209: $1000 \mathrm{mg} \mathrm{kg}^{-1}, 2000 \mathrm{mg} \mathrm{kg}^{-1}$, odnosno $4000 \mathrm{mg} \mathrm{kg}^{-1}$ tjelesne težine po danu. Preostale životinje bile su podijeljene u devet grupa kojima su bile dozirane različite koncentracije kadmija $\mathrm{i}$ dekabromiranog difenil etera (3x3 dizajn). Rezultati pokazuju da Cd+BDE209 smjesa u većoj mjeri remeti homeostazu hormona štitnjače u odnosu na pojedinačne spojeve.

KLJUČNE RIJEČI: BDE209, Cd, stimulirajući hormon štitnjače, tiroksin, trijodtironin

\section{CORRESPONDING AUTHOR:}

Marijana Ćurčić

Department of Toxicology „Akademik Danilo Soldatović”

Faculty of Pharmacy, University of Belgrade

Vojvode Stepe 450, 11221 Belgrade, Serbia

E-mail:makitox@pharmacy.bg.ac.rs 